Engineer Research and

Development Center

Center for the Advancement of Sustainability Innovations (CASI)

\title{
Material Life Cycle Analysis for the Reduction of Waste Generation at Military Installations
}

Giselle Rodriguez, Dominique Gilbert, M. Zllur Rahman, February 2017 Jorge Flores, Peter Stynoski, Cate Fox-Lent, and Igor Linkov

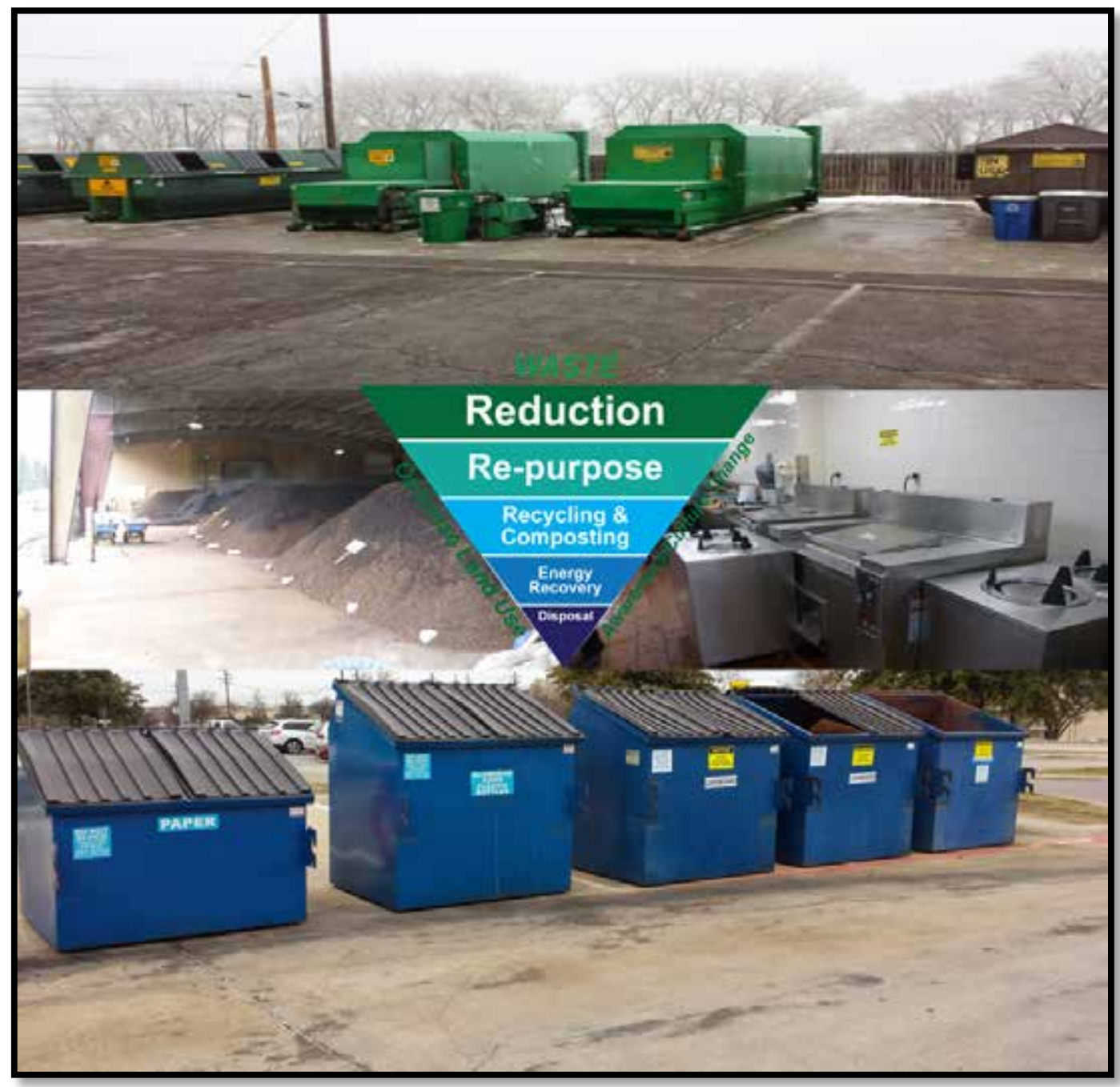

Approved for public release; distribution is unlimited. 
The U.S. Army Engineer Research and Development Center (ERDC) solves the nation's toughest engineering and environmental challenges. ERDC develops innovative solutions in civil and military engineering, geospatial sciences, water resources, and environmental sciences for the Army, the Department of Defense, civilian agencies, and our nation's public good. Find out more at wwwerdc.usacearmy.mil.

To search for other technical reports published by ERDC, visit the ERDC online library at http:/ / acuc.sdp.sirsi.net/ dient/ default. 


\section{Material Life Cycle Analysis for the Reduction of Waste Generation at Military Installations}

Giselle Rodriguez, Dominique Gilbert, M. Zllur Rahman, Jorge Flores, and Peter Stynoski

U.S. Army Engineer Research and Development Center (ERDC) Construction Engineering Research Laboratory (CERL) 2902 Newmark Dr.

Champaign, IL 61824

Cate Fox-Lent and Igor Linkov

U.S. Army Engineer Research and Development Center Environmental Laboratory (EL)

3909 Halls Ferry Road

Vicksburg, MS 39180-6199

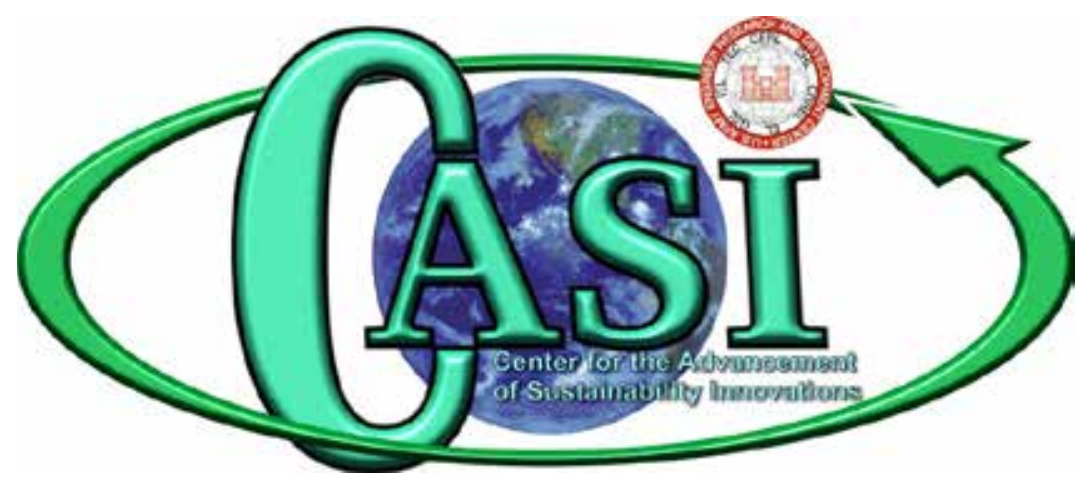

Final Report

Approved for public release; distribution is unlimited. 


\section{Abstract}

In 2011, the U.S. Army implemented the Net Zero Initiative, which includes Net Zero Energy, Net Zero Water, and Net Zero Waste (NZW). A NZW installation is an installation that reduces, reuses, and recovers waste streams by converting them to resource value without using a landfill. To assist in that effort, this work reviewed the policies and initiatives aimed at reduction of waste generation, discussed the challenges on the implementation of improvement efforts, and outlined existing research and operational needs to support more efficient operations and the achievement of Net Zero goals.

DISCLAIMER: The contents of this report are not to be used for advertising, publication, or promotional purposes. Citation of trade names does not constitute an official endorsement or approval of the use of such commercial products. All product names and trademarks cited are the property of their respective owners. The findings of this report are not to be construed as an official Department of the Army position unless so designated by other authorized documents. 


\section{Executive Summary}

In 2011, to address Executive Orders and the U.S. Department of Defense (DoD) Strategic Sustainability Performance Plan goals, the U.S. Army implemented the Net Zero Initiative. The main goal of the strategy is to integrate sustainability practices at the installation level to preserve the flexibility to operate in constrained economic or environmental circumstances. The first step in the strategy was to select the Net Zero Installation Pilots, and to divide the effort into three categories: Net Zero Energy, Net Zero Water, and Net Zero Waste (NZW). A Net Zero Energy installation is defined as an installation that produces as much energy on site as it uses. A Net Zero Water installation is an installation that limits the consumption of fresh water resources and returns the water back to the same watershed. A NZW installation is an installation that reduces, reuses, and recovers waste streams by converting them to resource value without using a landfill. Pilot installations should achieve these goals by Fiscal Year 2020 (FY20) (Hammack 2011).

The approach taken to create a NZW installation is similar to the one used to create a net zero energy installation. A NZW installation reduces, reuses, and recovers waste streams, converting them to resource values with zero landfill over the course of a year. The components of net zero solid waste include reducing the amount of waste generated, re-purposing waste, maximizing the recycling of waste stream to reclaim recyclable and compostable materials, and recovering waste to generate energy as a byproduct of waste reduction; ultimately, the effective implementation of these components entirely eliminates waste disposal. The best strategy to achieving NZW is to consider the waste stream when purchasing items, by reducing the volume of packaging, by reusing as much as possible, and by recycling the rest. A true cradle-to-cradle strategy considers the end state at the time the purchase decisions are made. A NZW strategy eliminates the need for landfills, protects human health, optimizes the use of limited resources, and maintains a clean environment (HQDA 2012).

Since 2011, the pilot initiative has evolved into an Army-wide mandate. U.S. Army installations have made great progress in their efforts to become Net Zero and toward meeting and exceeding diversion goals. However, even though much progress has been made to date, more work remains to be done. This is due partly to the current focus on waste diversion rather than waste minimization (i.e., reduction in waste generation). Waste diversion 
requires changes mostly at the end of the material life cycle; waste generation reduction requires changes throughout the material life cycle that often include the initial sourcing and procurement. Identifying and implementing appropriate changes to minimize waste takes careful measurement and planning across many operational activities that influence almost all Army efforts. A waste minimization approach considers not only the kind of products that are discarded, but also how those products are used, and even whether or not the use itself is needed. Since every installation is unique, the material needs for any individual installation will also be unique.

The materials predominantly disposed as waste in Army installations are food, cardboard, plastics, and paper products. These materials are mostly generated at barracks, instruction buildings, and dining facilities (DFACs). Most of these materials, which are currently being transported to the landfill at a cost to the installation, may potentially be diverted from the landfill. By far the two largest contributors to the solid waste stream are food and construction and demolition (C\&D) waste.

Waste characterizations have revealed that food waste is the largest single component of the overall waste stream at all Army installations, up to more than $50 \%$ of the total waste generation at some installations. By weight, some installations are generating more tons of food waste a year than paper and plastic combined. DFACs are the main contributor for such large amounts of food waste.

Because the material flow of food is influenced by a number of different entities within DoD, and because food waste on an installation passes through several stages of production including delivery, preparation, and consumption, many factors contribute to this waste stream. Moreover, since Army installations vary in population, land area, and mission, there is no "one size fits all" answer for managing food waste across all installations. Different installations will require different food management agendas. Nevertheless, some broad lessons can be applied generally across installations to minimize food waste at DFACs.

C\&D debris accounts for an estimated 35 to $40 \%$ of the municipal solid waste stream on installations. The typical volume of demolition debris generated per square foot of floor area, is $3.0 \mathrm{cu} \mathrm{ft}$ for brick and concrete construction and $4.5 \mathrm{cu} \mathrm{ft}$ for wood structures. For brick structures, up to $80 \%$ of the demolition waste generated has potential for diversion; for 
concrete structures, $50 \%$ of the demolition waste generated could be diverted; for wood structures, $90 \%$ of the demolition waste generated could potentially be diverted.

New construction technologies are emerging to develop standardized structural units that are designed for deconstruction and reuse, e.g., onsite-precast slabs and beams with interlocking arms and threaded inserts for lifting hooks. The chances for successful development and implementation of this and other concrete recycling technologies could be improved by partnering with university research groups and trade associations.

This work reviewed the policies and initiatives aimed at reducing waste generation, examined the challenges associated with the implementation of such improvement efforts, and outlined existing research and operational needs to support more efficient operations and to achieve the goals of NZW.

Even though the Army has made good progress toward meeting diversion goals in the last few years, this work concludes that installations need to further emphasize waste minimization and waste avoidance practices. Additional research is needed to develop and improve practices and technologies that address materials earlier in their life cycle to prevent them from entering the waste stream. Specifically, research is needed to develop:

- Army-specific design for deconstruction guidance

- food waste tracking software

- decision tools for prioritizing food waste reduction plans given the tracking data

- decision tools for managing municipal solid waste and C\&D waste depending on the size, location, age, and resources of a given installation

- publications and presentation of Army waste management issues and research to develop better contacts with the academic and industry communities and to find partners for pilot studies

- methods to identify, aggregate, and review regulatory barriers that limit the effectiveness of waste reduction and diversion techniques. 


\section{Contents}

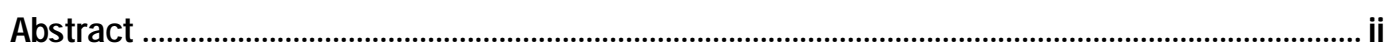

Executive Summary............................................................................................................. ii

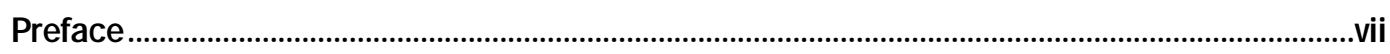

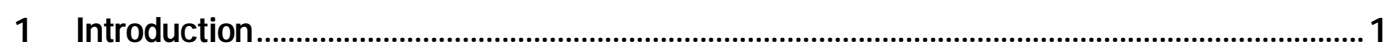

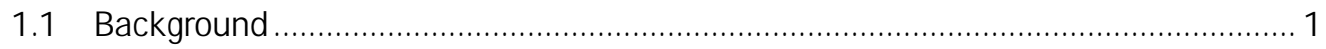

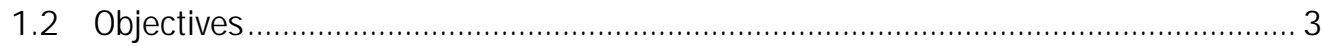

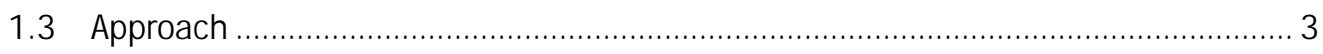

2 Policies that Motivate Sustainability and Waste Reduction.................................................... 4

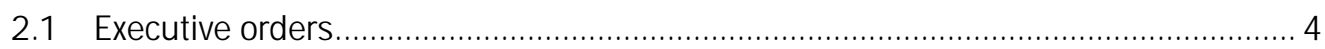

2.2 Strategic sustainability performance.

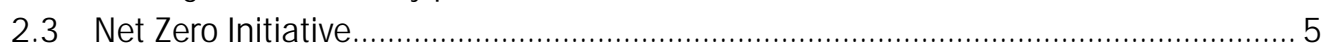

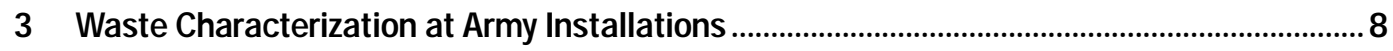

4 A Shift from Waste Diversion to Waste Minimization ........................................................10

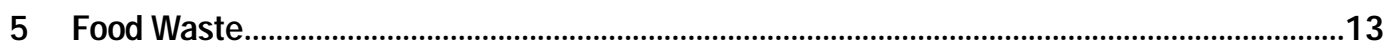

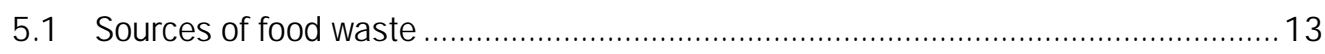

5.2 Challenges and opportunities for food waste reduction........................................ 15

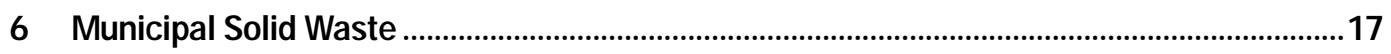

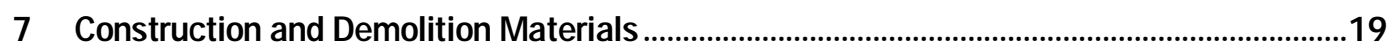

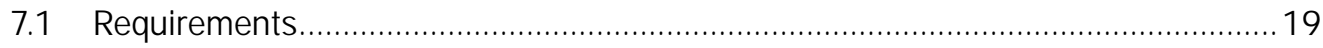

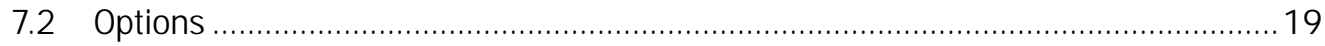

7.3 Challenges and opportunities for construction and demolition waste

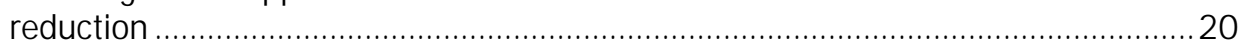

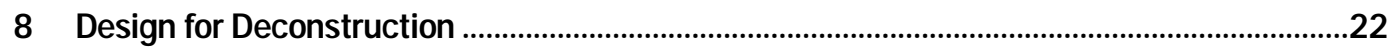

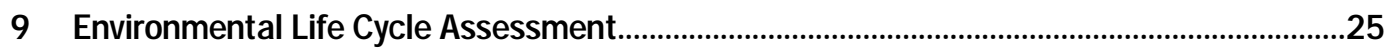

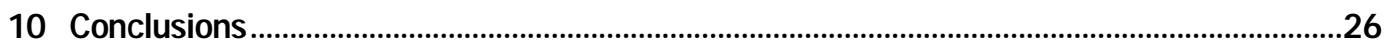

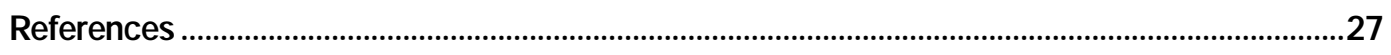

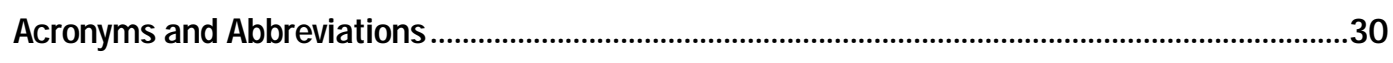

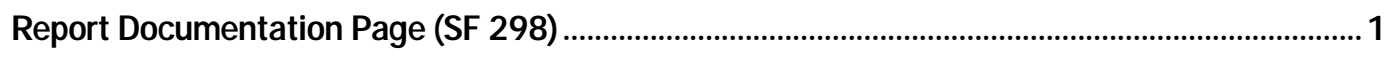




\section{Preface}

This study was performed under the Center for the Advancement of Sustainability Innovations (CASI). CASI was established by the U.S. Army Engineer Research and Development Center (ERDC) as a new capability in 2006, hosted at the Construction Engineering Research Laboratory (CERL) in Champaign, IL. CASI's mission is to focus ERDC expertise, technologies and partnerships toward helping the U.S. Army Corps of Engineers (USACE), the Army, and the Department of Defense (DoD) achieve more sustainable missions, facilities, and operations. The technical monitor and Associate Director of CASI was Franklin H. Holcomb. Dr. Patrick Deliman of ERDC-EL and David Ringelberg of ERDC-CRREL were Advisory Board members of CASI.

The work was performed by the Environmental Processes Branch (CNE) of the Installation Division (CN), CERL, Champaign IL and the Environmental Processes Branch (EPP) of the Environmental Process and Engineering Division (EP), Environmental Laboratory (EL), Vicksburg, MS. At the time of publication, H. Garth Anderson was Chief (CEERD-CNE); and Dr. Brandon Lafferty was Chief (CEERD-EPP); Michelle Hanson was Chief (CEERD-CN) and Warren P. Lorentz was Chief (CEERD-EP). Alan Anderson (CEERD-CVT) was the CERL Technical Director for Military Ranges and Lands and Dr. Patrick N. Deliman (CEERD-EVE) was the EL Technical Director for Environmental Modeling and Assessment. The Deputy Director of ERDC-CERL was Dr. Kirankumar Topudurti and the Director was Dr. Ilker Adiguzel; the Deputy Director of ERDC-EL was Dr. J ack E. Davis and the Director was Dr. Beth C. Fleming.

COL Bryan S. Green was Commander of ERDC, and Dr. J effery P. Holland was the Director. 
THIS PAGE INTENTIONALLY LEFT BLANK 


\section{Introduction}

\subsection{Background}

In 2011, to address Executive Orders and the U.S. Department of Defense (DoD) Strategic Sustainability Performance Plan goals, the U.S. Army implemented the Net Zero Initiative. The main goal of the strategy is to integrate sustainability practices at the installation level to preserve the flexibility to operate in constrained economic or environmental circumstances. The first step in the strategy was to select the Net Zero Installation Pilots, and to divide the effort into three categories: Net Zero Energy, Net Zero Water, and Net Zero Waste (NZW). A Net Zero Energy installation is defined as an installation that produces as much energy on site as it uses. A Net Zero Water installation is an installation that limits the consumption of fresh water resources and returns the water back to the same watershed. A NZW installation is an installation that reduces, reuses, and recovers waste streams by converting them to resource value without using a landfill. Pilot installations should achieve these goals by Fiscal Year 2020 (FY20) (Hammack 2011).

The approach taken to create a NZW installation is similar to the one used to create a net zero energy installation. A NZW installation reduces, reuses, and recovers waste streams, converting them to resource values with zero landfill over the course of a year. The components of net zero solid waste include reducing the amount of waste generated, re-purposing waste, maximizing the recycling of waste stream to reclaim recyclable and compostable materials, and recovering waste to generate energy as a byproduct of waste reduction; ultimately, the effective implementation of these components entirely eliminates waste disposal. The best strategy to achieving NZW is to consider the waste stream when purchasing items: to reduce the volume of packaging, to reuse as much as possible, and to recycle the rest. A true cradle-to-cradle strategy considers the end state at the time the purchase decisions are made. A NZW strategy eliminates the need for landfills, protects human health, optimizes the use of limited resources, and maintains a clean environment (HQDA 2012).

Since 2011, the pilot initiative has evolved into an Army-wide mandate. U.S. Army installations have made great progress in their efforts to be- 
come Net Zero and toward meeting and exceeding diversion goals. However, even though much progress has been made to date, more work remains to be done. This is due partly to the current focus on waste diversion rather than waste minimization (i.e., reduction in waste generation). Waste diversion requires changes mostly at the end of the material life cycle; waste generation reduction requires changes throughout the material life cycle that often include the initial sourcing and procurement. Identifying and implementing appropriate changes to minimize waste takes careful measurement and planning across many operational activities that influence almost all Army efforts. A waste minimization approach considers not only the kind of products that are discarded, but also how those products are used, and even whether or not the use itself is needed. Since every installation is unique, the material needs for any individual installation will also be unique.

The materials predominantly disposed as waste in Army installations are food, cardboard, plastics, and paper products. These materials are mostly generated at barracks, instruction buildings, and DFACs. Most of these materials, which are currently being transported to the landfill at a cost to the installation, may potentially be diverted from the landfill. By far the two largest contributors to the solid waste stream are food and construction and demolition (C\&D) waste.

Waste characterizations have revealed that food waste is the largest single component of the overall waste stream at all Army installations, up to more than $50 \%$ of the total waste generation at some installations. By weight, some installations are generating more tons of food waste a year than paper and plastic combined. DFACs are the main contributor for such large amounts of food waste.

Because the material flow of food is influenced by a number of different entities within DoD, and because food waste on an installation passes through several stages of production including delivery, preparation, and consumption, many factors contribute to this waste stream. Moreover, since Army installations vary in population, land area, and mission, there is no "one size fits all" answer for managing food waste across all installations. Different installations will require different food management agendas. Nevertheless, some broad lessons can be applied generally across installations to minimize food waste at DFACs. 
C\&D debris accounts for an estimated 35 to $40 \%$ of the municipal solid waste stream on installations. The typical volume of demolition debris generated per square foot of floor area, is $3.0 \mathrm{cu} \mathrm{ft}$ for brick and concrete construction and $4.5 \mathrm{cu} \mathrm{ft}$ for wood structures. For brick structures, up to $80 \%$ of the demolition waste generated has potential for diversion; for concrete structures, $50 \%$ of the demolition waste generated could be diverted; for wood structures, $90 \%$ of the demolition waste generated could potentially be diverted.

New construction technologies are emerging to develop standardized structural units that are designed for deconstruction and reuse, e.g., onsite-precast slabs and beams with interlocking arms and threaded inserts for lifting hooks. The chances for successful development and implementation of this and other concrete recycling technologies could be improved by partnering with university research groups and trade associations.

This work reviewed the policies and initiatives aimed at reducing waste generation, examined the challenges associated with the implementation of such improvement efforts, and outlined existing research and operational needs to support more efficient operations and to achieve the goals of NZW.

\subsection{Objectives}

This objectives of this work were to review the policies and initiatives aimed at reduction waste generation, explore the challenges on the implementation of improvement efforts, and outline existing research and operational needs to support more efficient operations and the achievement of Net Zero goals.

\subsection{Approach}

A review was conducted of the Army policies and initiatives aimed at reduction waste generation. Subject matter experts (SMEs) were engaged to explore the challenges on the implementation of improvement efforts. The results of these efforts were distilled into an outline of existing research and operational needs to support more efficient operations and the achievement of Net Zero goals. 


\section{Policies that Motivate Sustainability and Waste Reduction}

\subsection{Executive orders}

Executive Order (EO) 13693, Planning for Federal Sustainability in the Next Decade (White House 2015) is the main driver for Sustainability efforts within DoD and the Army. The overarching focus of this EO is the reduction of greenhouse gas emissions through changes in Federal Agency processes and procedures in areas such as supply chain management; emissions reductions; energy efficiency; and use of alternative energy, fleet management, waste management, and affirmative procurement. This EO revoked, and changes or enhances the following goals detailed in EO 13514 (White House 2009) and EO 13423 (White House 2007):

- EO 13693 (paras. 3(j)(ii),(iii)) retains the waste reduction goal set forth in EO 13514 of diverting 50\% of non-hazardous solid waste and 50\% of construction debris, and enhances this goal by specifying that that nonhazardous waste includes compostable material.

- EO 13693 retains the goal of employing environmentally sound practices with respect to the agency's disposition of all agency excess or surplus electronic products.

- EO 13693 retains and expands the goals for environmentally sustainable procurement as part of the process change to reduce the amount of solid/ hazardous waste generated by Federal facilities.

- EO 13693 (para §3(a)(i)) retains an energy intensity (Btu/GSF)* goal of annual reduction of 2.5\% FY16 through FY25.

- EO 13693 (para §3(c)) sets the following renewable energy targets:

o $10 \%$ in FY16- 17 15\% in FY18- 19

o $20 \%$ in FY20-2125\% in FY22- 23

o $30 \%$ by FY25.

\subsection{Strategic sustainability performance}

The objective of the DoD Strategic Sustainability Performance Plan (SSPP) (DoD 2012) is to ensure that sustainability becomes thoroughly woven into the fabric of the DoD's daily mission. J ust as sustainability directly affects the ability of DoD to perform its mission in the future, so does the Depart-

\footnotetext{
* Gross Square Foot (GSF)
} 
ment's ability to be resilient to the impacts of climate change. Sustainability and adaptation to climate change go hand in hand with DoD's efforts to ensure resilience and success. The DoD SSPP has parallel goals for waste diversion. This is consistent with past waste reporting, and management practices. The SSPP Goal 5, "Solid Waste Minimized and Optimally Managed" encompasses the following sub-goals:

- Sub-Goal 5.1 All DoD Components implementing policies by FY14 to reduce the use of printing paper

- Sub-Goal $5.250 \%$ of Non-Hazardous solid waste diverted from the waste stream by FY15, and Thereafter Through FY20

- Sub-Goal 5.3 60\% of Construction and Demolition Debris Diverted from the Waste Stream by FY15, and Thereafter Through FY20

- Sub-Goal 5.4 Ten landfills or wastewater treatment facilities recovering biogas for use by DoD by FY20.

Reducing food waste to landfill will increase diversion rates, will reduce greenhouse gases, i.e., by burning methane from food waste for energy rather than releasing it into the atmosphere, and in most areas, and will save installations considerable funding in hauling costs and landfill tipping fees. Reducing the amount of construction and municipal solid waste that is disposed in landfills can yield similar cost savings and reduce the carbon emissions associated with transportation of waste to the dump site. Moreover, these efforts will support the following Acts and Executive Orders:

- EO 13514 (White House 2009)

- EO 13423 (White House 2007)

- EO 13148 (White House 20oo)

- Army Regulation (AR) 200-1(HQDA 2007a)

- The Energy Independence and Security Act (EISA 2007).

\subsection{Net Zero Initiative}

In 2011, the U.S. Army implemented the Net Zero Initiative to address EOs and the SSPP goals described above. In J anuary 2014 the Secretary of the Army distributed the Army Directive 2014-02, "Net Zero Installations Policy" (McHugh 2014). This memorandum set policy and assigned responsibility to strive toward Net Zero at all Army installations. The policy applies to all permanent Active Army, Army National Guard, and U.S. Army Reserve installations. The policy directs Commands to implement Net Zero to the maximum extent. For Net Zero Waste, the policy directs installations to reduce, reuse, recycle/compost, and recover solid waste streams, and to 
convert them to resource values-practices that will ultimately result in zero landfill disposal. Also, the original Net Zero pilots will continue to strive to reach their Net Zero goal by FY20.

The concept of NZW states that no waste should go to landfill over the course of 1 year. A combination of different waste management practices along the life cycle of the installation should be applied to accomplish this goal. These practices are divided in two main components: waste minimization and waste diversion. The waste minimization component of the Net Zero Strategy encourages the installations to reduce waste at the source by engaging in sustainable purchasing of materials that generate less waste, have less packaging, are reusable and recyclable, etc. The second component, waste diversion, refers to the processes and technologies the installation can use to prevent its waste from going to the landfill. Some examples of alternative landfill disposal are recycling, composting, and waste-to-energy technologies, etc.

Figure 1 presents the progress the Army has made for waste diversion (from FY10 to FY13) as reported in the U.S. Army Sustainability Report of 2014 (DA 2014). It is important to note that, even though it appears that the diversion fell from $50.4 \%$ in FY12 to a $43.3 \%$ in FY13, the reduction in total waste generated has been significant when compared to previous years. In addition, the Army continues to progress toward exceeding waste diversion goals with an overall diversion rate of $49.2 \%$ for FY14 and $51.4 \%$ for FY15. The current Army per capita waste generation is approximately $2.3 \mathrm{lb}$ per person per day.

Despite the Army's progress to date toward meeting these goals, there is more work to be done. There is partly due to the need to shift the focus from waste diversion to waste generation reduction. Waste diversion requires changes mostly at the end of the material life cycle whereas waste generation reduction requires changes throughout the material life cycle, often including the initial sourcing and procurement. Identifying and implementing the appropriate changes takes careful measurement and planning across many operational activities influencing almost all Army missions. The following chapters discuss these needs and challenges. 
Figure 1. U.S. Army diversion of solid waste and C\&D from landfills (FY10-FY13).

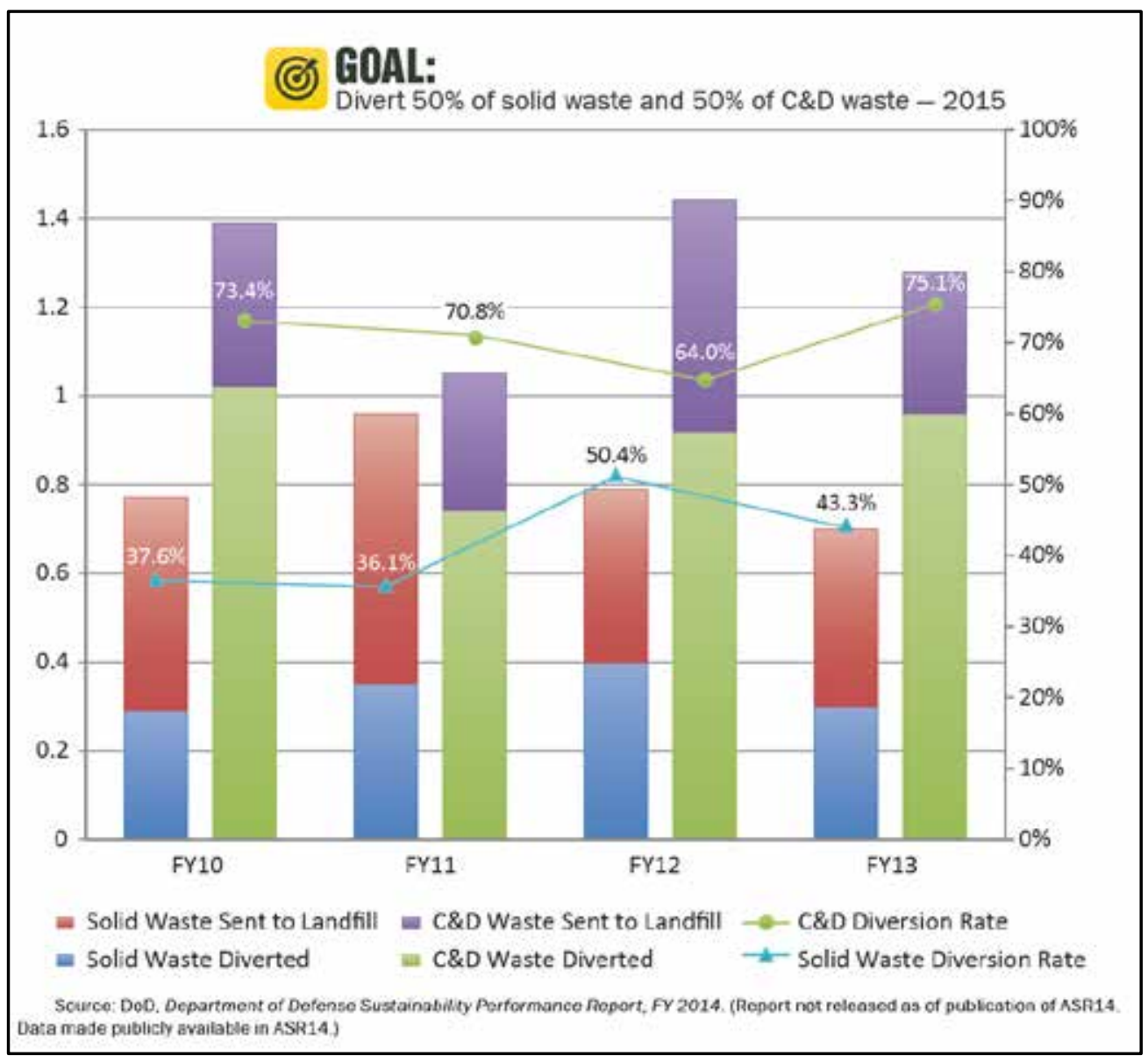

Source: DA (2014). 


\section{Waste Characterization at Army Installations}

Waste characterization provides installations with quantitative data related to waste types generated, and to waste generation and distribution trends based on building usage. The ERDC-CERL team has developed a unique process based on the methodology from American Society for Testing and Materials (ASTM) D5231, Standard Test Method for Determination of the Composition of Unprocessed Municipal Solid Waste (ASTM 2008).

This process is unique because it develops waste "intensity" factors for each building type and waste type, e.g., \#1 plastic at offices, or cardboard at DFACs. These factors are generated after doing intensive sorting at representative buildings of each type. Waste characterization may then be extrapolated across the installation based on the real property inventory. The waste is sorted by hand into at least 19 categories, including all the plastics, food, and different types of paper. Categories might be added depending on an individual installation's need. Figure 2 shows an example of waste types found at three different installations: Fort Leonard Wood, MO, Fort Huachuca, AZ, and Presidio of Monterey, CA.

The materials that are predominantly disposed as waste at Army installations are food, cardboard, plastics, and papers. These materials are mostly generated at barracks, instruction buildings, and DFACs. Most of these materials can potentially be diverted from the landfill, where they are currently being transported at a cost to the installation.

Conducting these waste characterizations has revealed a common trend present at all installations: food waste is the largest single component of the overall waste stream. At some installations, food waste represents up to more than $50 \%$ of the waste generation. By weight, some installations are generating more tons of food waste a year than paper and plastic combined. 
Figure 2. Waste types found at Amy installations.

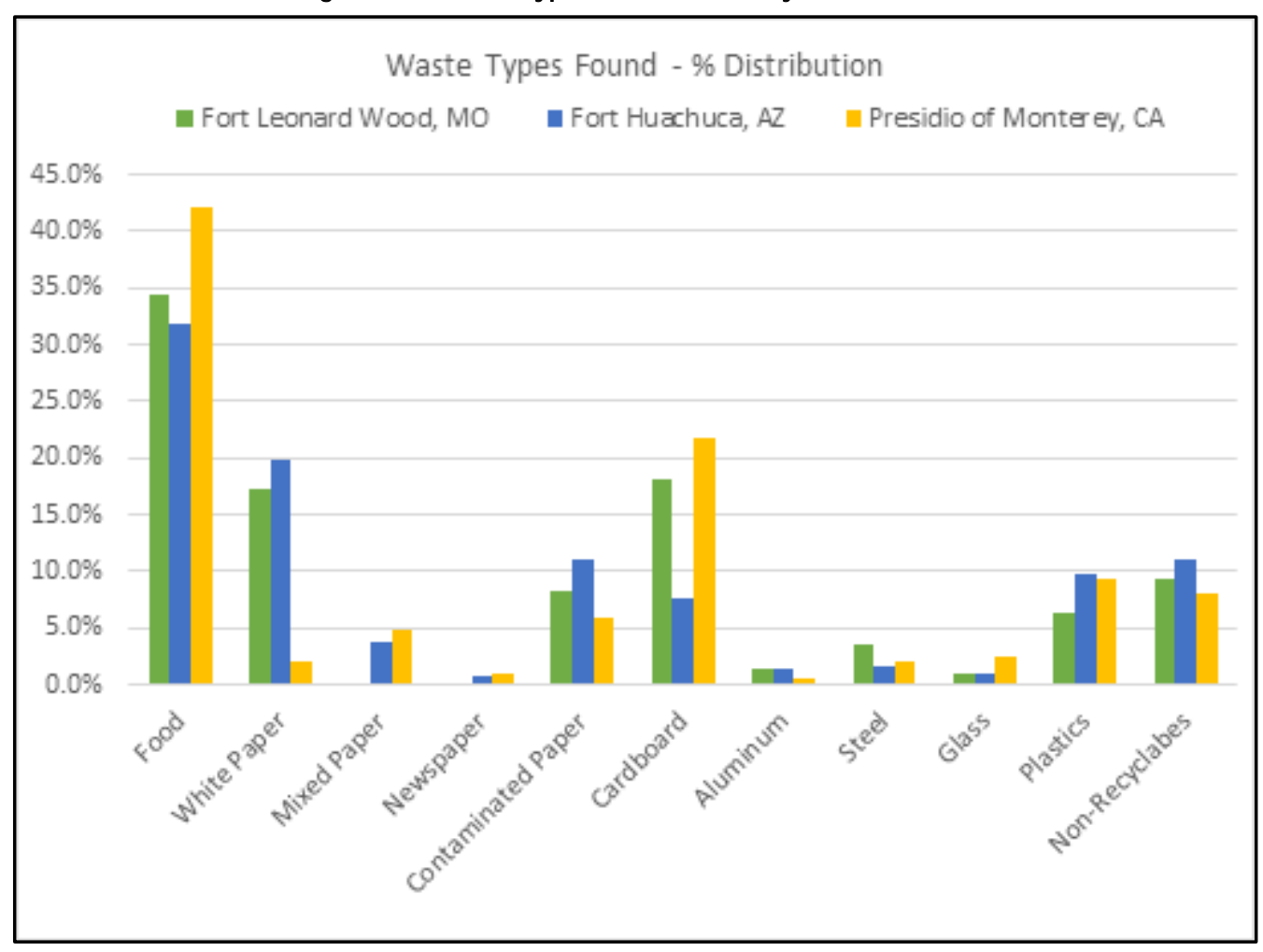

A better determination of the kind of materials being disposed and the locations where they are generated can enable installations to maximize the diversion potential of these materials by focusing their recycling program resources. This process helps installations to prioritize diversion strategies and places the focus on the materials that offer the most opportunities for diversion, either because their markets are readily accessible or because the materials are generated in the highest quantities. Whether these diversion strategies include waste minimization by better purchasing, or by recycling and composting, the process of identifying and quantifying these materials often makes difference between meeting and exceeding mandated diversion goals. 


\section{A Shift from Waste Diversion to Waste Minimization}

Waste minimization is not a new concept to the Army or to the Federal government. The Federal Pollution Prevention Act of 1990 (PPA 1990), which covers waste minimization as source reduction, defines the term as any practice that:

1. reduces the amount of any hazardous substance, pollutant, or contaminant entering any waste stream or otherwise released into the environment (including fugitive emissions) prior to recycling, treatment, or disposal; and

2. reduces the hazards to public health and the environment associated with the release of such substances, pollutants, or contaminants. The term includes equipment or technology modifications, process or procedure modifications, reformulation or redesign of products, substitution of raw materials, and improvements in housekeeping, maintenance, training, or inventory control.

In addition, the U.S. Army Net Zero Waste Hierarchy (Figure 3) gives great emphasis to source reduction efforts when striving for net zero. The Net Zero Initiative identifies a number of waste reduction practices such as: establishing affirmative procurement programs, performing waste characterizations, implementing food donation programs, and making efforts to reduce an installation's overall waste generation. In this same vein, while recycling, composting, and energy recovery efforts are all elements that can help installations reach their NZW goal, waste reduction programs should also be evaluated and implemented to the greatest extent possible.

Figure 3. U.S. Army NZWhierarchy.

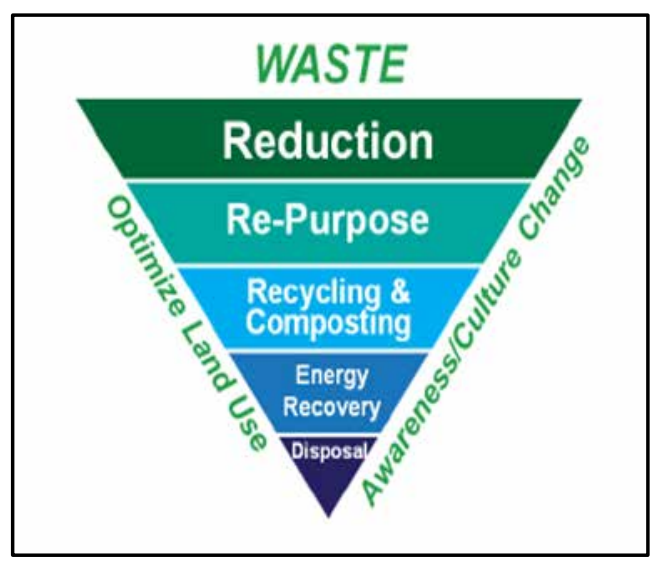


Compared to waste diversion, waste minimization practices require more planning and coordination within different organizations inside the installation and even within the Army at an enterprise level. For example, a recycling program (or Qualified Recycling Program [QRP]) would only have to coordinate operations with the installation's Directorate of Public Works (DPW), Logistics Readiness Command (LRC) and perhaps Morale, Welfare, and Recreation (MWR) functions to successfully divert materials from the landfill. A waste minimization effort might require coordination with multiple organizations at the leadership and at the staff level. The user, the procurement staff, support organizations, tenants, etc. are critical elements that define whether a material is or is not used.

A waste minimization approach not only takes into consideration what kind of products are discarded, but also how those products are used, and whether or not that use is needed. Every installation is unique, therefore the material needs of any given installation will also be unique. Therefore, standardized practices at the enterprise level are commonly the cause for discrepancies in the definition of whether or not a material is needed and in what amount.

Material use and consumption is an issue that is not unique to the Army. Material consumption in the United States now exceeds 10 tons per person per year, while the global average consumption has grown to about 5 tons/ annum (Worrell and Reuter 2014). This large level of consumption calls for a re-evaluation in the way the nation as a whole uses resources. These materials are drawn from the Earth's natural resources, which are finite. In a U.S. Army perspective, material consumption shall take into consideration the efficiency of operations and force protection in addition to the extraction of the natural resource itself. Therefore, considerations on material life cycle are important.

The U.S. Environmental Protection Agency (USEPA) addresses material life cycles in their Sustainable Materials Management (SMM) Strategy. SMM is defined as an approach to serving human needs by using/ reusing resources productively and sustainably throughout their life cycles, generally minimizing the amount of materials involved and all associated environmental impacts

This strategic plan focuses on three areas: (1) the Built Environment, (2) Sustainable Food Management, and (3) Sustainable Packaging. Among 
other things, this program's main focus is to decrease the disposal rate by source reduction, reuse and recycling, and reduction of the environmental impacts of materials across their life cycle.

The Army has engaged in efforts that target waste minimization and address materials at the early stages of the life cycle. A series of policies and tools have been developed to assist Army installations minimize waste generation. Some examples of these tools are:

- Army Food Donation Procedures Memorandum. This document establishes procedures for providing excess food to food recovery and distribution organizations and lists all approved organizations to which donations can be sent.

- Sustainable Procurement Quick Guides. These two-page documents provide a quick check lists to determine what sustainable products may be included during routine operation for the following functions:

0 food services

o facilities and grounds maintenance

o military barracks and lodging

o morale, welfare, and recreation activities

o vehicles and vehicle maintenance. 


\section{Food Waste}

\subsection{Sources of food waste}

ERDC-CERL recently conducted waste characterizations at Fort Leonard Wood, MO, Fort Hood, TX, Fort Huachuca, CA, Fort Benning, GA, Presidio of Monterey, CA, and Camp Zama, J apan. These studies suggest that food represents the largest percentage of the waste stream across installations. At some installations as much as 1,000 lbs of DFAC food are discarded per day. This is largely a combination of uneaten, never-served, prepared, and postconsumer food, and paper products that Soldiers discard.

Because the material flow of food is influenced by a number of different entities within $\mathrm{DoD}$, and because food waste on an installation passes through several stages of production including delivery, preparation, and consumption, many factors contribute to this waste stream. The six areas in the food production services that contribute to food waste at DFACs, and the associated (responsible) parties are:

- the menu (handled by the J oint Culinary Center of Excellence)

- food orders (handled by the Installation Food Manager)

- food intake (brought in by commercial food distributor)

- food preparation (often prepared by contractors and sometimes military personnel both managed by LRC)

- disposal of unwanted food (by diners)

- transportation of food waste to landfill (managed by the DPW).

Food programs at Army installations are highly structured. A number of different entities and functions perform a vast amount of research and planning in designing these food programs, and a number of ARs dictate the guidelines these programs must follow. For example, AR 30-22, Army Food Program (HQDA 2012c), stipulates that meals must: follow published nutrition standards; be wholesome, nutritious, and balanced; offer variety; be complementary; and include currently popular food items. AR 30-22 also establishes the minimum caloric requirements for meal plans, which, for military personnel doing heavy work or performing prolonged, vigorous physical training, can be upwards of 4,000 - 5,000 calories/ day. Department of the Army Pamphlet (DA PAM) 30-22 (HQDA 2007b) details the food variety and elements of an a la carte menu that must be provided at each meal. These can include multiples of choices during each of the three meals (breakfast, lunch, and dinner) on a daily basis. In short, 
these regulation can result in large volumes of food served and disposed on a daily basis at Army installations across the country.

However, Army regulations also target food waste. Some offer budgetary controls (defined by the basic daily food allowance) while others focus on the waste in food production lines. AR 30-22, for example, states that any installation implementing an a la carte dining program will also "undertake an extensive training program" that must include "progressive cookers, ...leftover control, and most importantly, portion control or serving size." Progressive cooking is a measure designed specifically to prevent "excessive waste" (DA PAM 30-22). Progressive cooking can achieve waste control by using historical data on customer preferences and flow patterns and/ or by making sure servers on cafeteria lines are briefed on proper portion sizes and that portion sizes are adjusted to meet the recipe source.

These regulations are expansive and thorough in ensuring that Soldiers have access to a variety of healthy food, and they address many of the waste concerns that are an unavoidable consequence of serving large quantities of food. Nevertheless, there are still opportunities to further reduce waste. An analysis of the six areas of food production services listed above can reveal the components that contribute to food waste at DFACs:

1. Menus are designed to accommodate Soldiers' tastes, health, and caloric needs as much as possible, but on any given day if the Soldiers' do not like the menu, part (if not all) of the meal can end in the waste bin.

2. Food ordering follows strict budgetary guidelines. A well-managed food budget is one of the main tools used to manage and reduce waste. When ordering food, food managers are required to not spend over a specified amount, or under that amount by more than 3\%, as the entity (for whom the food manager works) is financially responsible for any overages. At the installation level, other successful efforts that can minimize waste are: creating accurate feeding projections, cooking only what is required for any given meal, and reducing the number of serving lines when Soldier populations drop.

3. When food arrives at the DFAC, it is inspected for freshness and inventory accuracy. This stage of food production results in the least food waste by ensuring that the majority of the food arrives fresh and unspoiled.

4. The food preparation stage inherently involves waste as the inedible parts of the prepared foods are discarded. Furthermore, the daily head-count for meals that are prepared are only as accurate as the food manager's information. When the food manager is not updated on troop movement 
changes, neither are the kitchen staff who prepare the meals. Though this does not happen often, when meal counts not adjusted down to accommodate troop changes, the result is food waste. Another serving event that contributes to DFAC food waste is the buffet style feeding, which on the one hand, satisfies Army regulations for variety and different tastes, but results in the preparation of more meals than will be eaten.

5. After the meal has been consumed, the diners dispose of uneaten portions and the kitchen staff discard the unserved/ unwanted prepared meals. During basic training, Soldiers have a set amount of time to eat a meal; whatever they do not finish during that timeframe is thrown out as waste. Furthermore, the food consumed in the field, by regulation (TB MED 530 [HQDA 2014]) cannot be used as leftovers and must be thrown away.

6. Finally, discarded food is hauled to landfill. Theinstallation pays a fee to haul the food waste to the landfill and tipping fees once the food has arrived at the landfill.

\subsection{Challenges and opportunities for food waste reduction}

The amount of food waste is not uniform across all installations. Different installations will create more or less waste according to their different missions and population sizes. However, all DFACs contribute food to the waste stream. Since it is a "given" that all food production services will produce a certain amount of food waste, the question is not whether to eliminate all food waste, but rather how to: (1) reduce, (2) reuse as much as possible of the food waste, (3) recover what is remaining that is recoverable to, (4) minimize as much as possible the food waste to be disposed.

There is no "one size fits all" answer for this issue. No single solution will accommodate all circumstances since Army installations vary broadly in population size, land area, and mission. For example, at installations with a training mission, Soldiers in basic training must eat in a fixed amount of time (and produce more waste) whereas at other installations, Soldiers might have greater flexibility (and produce less waste). This suggests that different installations will require different food management agendas.

Still, some broad lessons can still be applied generally across installations to minimize waste at DFACs. It is important to take a holistic approach to studying food waste, i.e., to consider food waste as one large problem rather than many independent problems from different organizations. This approach allows different groups to work together to find and test common solutions such as new technologies that help to reduce food waste, or 
improved practices that identify alternative uses for food that would otherwise be wasted:

1. Food waste tracking systems such as LeanPath, ${ }^{*}$ which are used with great success in the commencial sector to reduce food waste, represent one such technology that may find useful application at Army installations. Food waste tracking systems can be simple technologies with user friendly interfaces that record and display detailed data about weight, food-type, and location of food wasted. These programs are designed to generate data that will allow for a greater understanding of food processes such as delivery, pre- and post-consumer prep, numbers of extra meals prepared, and trends in the types of foods disposed. These types of systems tend to be inexpensive, and they can be rented for the amount of time the installation decides it needs to understand its food production processes.

2. Another type of technology that shows promise is a recovery system that uses anaerobic digestion to convert food waste to energy. Commencial technologies exist today that dispose of food waste in clean and easy ways by processing it into an energy-rich material for use in a local anaerobic digester. These organic recycling systems are scalable and designed to accommodate different volumes of food waste. Cost avoidance in hauling and tipping fees will depend on the type of system employed and the state theinstallation is located in.

3. The Army's food donation policy as published in the Army Policy Memorandum 31July 2014 (McHugh 2014) is an effective mechanism that helps to reduce food waste by allowing installations to donate excess foods (meal items nearing or at the sell by/ use by date; or packaged unopened components of operational rations or field kitchen meals) to recovery and distribution organizations. If implemented, food donation programs have the potential to significantly help reduce food waste in DFACs.

This small sampling of approaches that address food waste are only a few among many technologies applicable to handling food waste at DFACs that can help minimize food waste and reduce disposal costs.

\footnotetext{
* http:// unwleanpath.com/
} 


\section{Municipal Solid Waste}

The QRP has been a vital instrument that helps installations achieve waste diversion goals. Department of Defense Instruction (DODI) 4715.4 "Pollution Prevention" (DoD 1996) defines a QRP as organized operations that require concerted efforts to divert or recover scrap or waste, as well as efforts to identify, segregate, and maintain the integrity of the recyclable materials to maintain or enhance their marketability. If the program is administered by a DoD component, a QRP includes adherence to a control process providing accountability for all materials processed through program operations.

As part of the statutory exemption provided by 10 U.S.C. 2577, "Disposal of Recyclable Materials," for DoD, QRPs may retain the proceeds when they sell authorized recyclable materials. However, there are limitations to the use of those proceeds. Proceeds from the QRP must first be used to cover the costs of operations, maintenance, and overhead for processing recyclable material, including the cost of any equipment purchased for recycling purposes. Up to $50 \%$ of the balance remaining may then be used for P2, energy conservation, and occupational safety and health projects (not to exceed half the cost of a minor construction project). The remaining balance may be transferred to the non-appropriated fund (MWR) account at the installation. Proceeds may only be used for these three purposes. At the end of the fiscal year, any balance over $\$ 2,000,000$ in the QRP account reverts to the Treasury.

Several installations currently operate successful QRP programs that generate over $\$ 1$ million in proceeds every year by selling recyclable products. This translates into a financial benefit for installations, specifically into supporting MWR programs. Installations like Fort Hood, TX, J oint Base Lewis McChord, WA, and Fort Carson, CO (among many others) are examples of Army installations that maintain sustainable, profitable, long lasting QRPs.

But as any other program, a QRP has operational costs that need to be covered. The interpretation of what constitutes a QRP operational cost and what constitutes an inherent installation responsibility is very important 
for the success and feasibility of the program. In terms of material transportation and disposal, the current U.S. Army QRP Handbook of 2010 states that:

The installation, as part of its support mission, is responsible for refuse collection and disposal. Refuse collection, transportation, and disposal on or off the installation will be funded by installation Operations and Maintenance (O\&M) (BASOPS) funds. The installation is also fiscally responsible for segregated and non-segregated recyclable materials collected from the installation's non-privatized housing areas. The installation receives O\&M funds to collect refuse and scrap, regardless of whether its destination is the landfill or recycling center. However, if the cost of transportation to the recycling facility exceeds the cost of solid waste disposal, then QRP proceeds shall reimburse the difference to the O\&M account.

However, DODI 4715.4, Pollution Prevention will be replaced with a new DODI entitled, Integrated Recycling and Solid Waste Management, scheduled to be released before the end of calendar year 2016 (CY16). This new instruction poses significant changes to QRP operations that might affect the capacity of some installations to operate such programs.

\section{Per the new DODI 4715.AC:}

Transportation and disposal of recyclables on or off the installation are funded by the installation O\&M. QRP costs of operations can include pick up and movement of materials to the QRP. QRP sales revenue reimburses O\&M accounts for those costs identified as QRP operations (e.g., separate line item for transportation contract).

In short, QRP revenues shall be used to reimburse the collection and transportation of the recyclable materials. If this new DODI is adopted, it will not be economically feasible to operate many QRPs with small to medium revenue streams, as they will not be able to sustain operations. The pickup and transportation of recyclables is a significant cost, and historically, an O\&M function of the installation. Given this new challenge that might limit the ability of conducting economically feasible recycling programs, it is even more important to shift the NZW focus from one driven toward meeting waste diversion goals to one based on waste minimization practices. Approaches like green procurement, material reuse, donations, waste processing and treatment technologies should then be the center of NZW programs. 


\section{Construction and Demolition Materials}

\subsection{Requirements}

C\&D debris accounts for an estimated 35 to $40 \%$ of the municipal solid waste stream on Army installations. To accommodate this great volume of waste, Policy Letter \#6-14, "Non-Hazardous Solid Waste Management Policy" (HQIMCOM 2014) requires that "all military construction, major renovation, and demolition activities shall include C\&D waste management requirements in the solicitation documents."

The typical volume of demolition debris generated per square foot of floor area is $3.0 \mathrm{cu} \mathrm{ft}$ for brick and concrete construction and $4.5 \mathrm{cu} \mathrm{ft}$ for wood structures. Much of this demolition waste has a potential for diversion (HQUSACE et al. 2002):

- for brick structures, up to $80 \%$

- for concrete structures, $50 \%$

- for wood structures, $90 \%$.

Due to its prevalence and high density, concrete is the most common C\&D waste by weight at many Army installations. Because Army waste reduction goals are based on weight, diversion and recycling of waste concrete should be a focal point of waste reduction plans. In addition, portland cement production is responsible for approximately $7 \%$ of global anthropogenic $\mathrm{CO}_{2}$ emissions. Reuse or recycling of existing concrete may displace a portion of virgin material production and the related emissions. However, recycled concrete materials face challenges as they must maintain compliance with the performance, safety, environmental, and regulatory standards of virgin materials. Furthermore, most traditional cast-in-place concrete or concrete masonry unit (CMU) structures cannot be disassembled, instead recycling concrete structures typically requires demolition and crushing. CMUs are not likely to survive demolition as reusable units so they typically need to be crushed and used as aggregate.

\subsection{Options}

Current options for disposal of C\&D debris include:

- Deconstruction, in which "planned and controlled" dismantling of infrastructure preserves the integrity of the constituent material for reuse 
- Recovery/Reuse, which requires little or no processing for use in new projects

- Recycling, in which debris can be reprocessed for use in new manufactured materials

- Composting, which can be used if there is a sufficient amount of organic material (plant material, sawdust, food scraps, etc.)

- Burning/Incineration, which is used to simply dispose of material, or to generate energy as part of a waste-to-energy plant

- Indiscriminate Demolition with Landfill Disposal, which is the least cost effective and environmentally conscious method, and which is generally recommended for use only when other methods are impossible or unavailable.

Although many commercial entities can realize significant cost reductions through the sale of recyclable/ reusable/ compostable materials, as opposed to their disposal in landfills, installations are limited by the requirements of the QRP. In addition, most C\&D services are provided through contractors, which gives the Army less direct control over the methods used and the final waste management strategy.

\subsection{Challenges and opportunities for construction and demolition waste reduction}

Because approximately 65-75\% of concrete is composed of aggregates such as sand, gravel, and stone, it seems appropriate to consider reusing waste concrete as aggregate in road base or new concrete. However, the properties an content of recycled concrete aggregate deserve special consideration. Porous mortar and hydrated or unhydrated cement in recycled concrete can cause significant material property issues such as decreased modulus of elasticity, increased creep and drying shrinkage, potential for chemical attack, and increased water demand. Reinforced structures typically contain a significant fraction of steel as well although this material can be sorted by electromagnet and recycled as standard scrap. Manual inspection for reinforcing bar fragments may be required when recycled concrete is used for top courses of pavements to avoid tire and track punctures and personal injury.

The most common use of recycled concrete in the United States is pavement base and sub-base (J ones 2012). Other Army-relevant uses of recycled concrete aggregates include parking lots, trails, fire breaks, and soil stabilization. Recycled concrete aggregate fines can replace as much as 
$30 \%$ of the aggregate in virgin concrete without significant effects on hardened state mechanical properties (Evangelista and de Brito 2007). Recycled concrete aggregates are especially advantageous in regions lacking ample natural stocks of coarse aggregates due to logistics costs and associated $\mathrm{CO}_{2}$ emissions and energy requirements of transporting aggregates.

Further research is required to develop relevant standards and regulations for the use and stockpiling of recycled concrete. Regulations enacted without adequate field testing may have unintended consequences that may limit concrete recycling. For example, North American Industrial Classification System (NAICS) Code 32799 (NAICS 2012) in Washington State places an upper limit of $8.5 \mathrm{pH}$ at the point of discharge from a recycled aggregate road base. Even though only about $2 \%$ of field measurements in one experiment exceeded this limit (Chen, Tinjum, and Edil 2013), such measurements would preclude the use of recycled aggregates in the studied application.

New construction technologies are emerging to develop standardized structural units that are designed for deconstruction and reuse, e.g., onsite-precast slabs and beams with interlocking arms and threaded inserts for lifting hooks. The chances for successful development and implementation of this and other concrete recycling technologies could be improved by partnering with university research groups such as the Recycled Materials Resource Center (RMRC 2016), and trade associations such as the Construction \&Demolition Recycling Association (CDRA 2016). Low-risk demonstration projects at Army facilities would have the potential to achieve high visibility in academia and industry when working alongside these broad-based partners.

The key challenges facing concrete waste recycling on Army installations are:

- the logistics and costs of onsite crushing, grading, and stockpiling of reclaimed material

- the untested effects of high $\mathrm{pH}$ leachates on surrounding infrastructure and environments (Chen, Tinjum, and Edil 2013)

- regulatory barriers such as state Departments of Transportation (DOT) disallowing the use of recycled concrete or Army-mandated time limits on stockpiling of solid wastes

- the availability and accuracy of life cycle assessment and cost analysis tools to justify the use of recycled concrete on technical and financial bases

- the need for new construction design to better focus on end-of-life deconstruction and reuse as an alternative to demolition and diversion of concrete waste. 


\section{Design for Deconstruction}

As buildings continue to be removed and replaced throughout the Army, C\&D waste has become a growing point of discussion within Army circles. One focus of these discussions is the need for better ways to mitigate C\&D waste to minimize the amount of waste sent to the landfills. The mitigation strategy that has drawn the most attention is that of deconstruction. On 16 December 2013, the Assistant Secretary of the Army for Installations Management, Energy, and Environment (ASA-IE\&E) issued an Sustainable Design and Development (SDD) Policy Update in an attempt to implement, to some degree, this C\&D waste mitigation strategy (Hammack 2013). According to this SDD Policy Update, requirements for C\&D waste reduction are stated as:
Construction Waste Management. The DoD Strategic SSPP (DoD 2012, reference 1.q) requires that at least $60 \%$ of construction and demolition debris be diverted from the waste stream by FY15. However, it is the Army's intent to manage waste with the goal of NZW disposal in landfills. Therefore, projects that involve the removal of existing buildings or structures will evaluate the feasibility of deconstruction and salvage ra- ther than conventional demolition, and will implement deconstruction wherever markets or on-site reuse opportunities exist or are anticipated.

The SDD Policy Update supports the Army's intent to reach NZW landfill goal, and expresses the desire to surpass the $60 \%$ diversion requirement mentioned. Nevertheless, the policy update leaves room for interpretation as to what constitutes "feasibility of deconstruction" and ultimately how to "implement deconstruction." Due to this unintentional yet apparent ambiguity within the mandate, projects in which deconstruction seems to be a perfect demolition alternative still bypass the method. One good example is Soldiers Plaza demolition project at Fort Benning, GA. This \$1.4 million project, kicked off on 15 February 2016, includes the removal of 45 facilities totaling nearly $407,000 \mathrm{SF}$. Thirty-one of the 45 facilities, almost 120,000 SF, are World War II-era wood structures, which are prime candidates for currently accepted deconstruction methods (Newcomb 2016).

This issue is well documented (Napier, Flores, and Schneider 2015). There is a need to clarify (or otherwise removing the impact of) the ambiguity in the mandate to give installations the most effective means to reach the Army's intent to surpass the $60 \%$ diversion requirement, and also to reach 
the Net Zero Waste Army goal. In the near future, the Army will remove and replace a significant number of older buildings. This represents an opportunity to not merely encourage and implement deconstruction at the end of building life phase, but to plan and design for deconstruction before construction begins. Past guidance focused on the deconstruction of World War II-era wood-framed buildings. However, current candidates for dismantling are no longer of wood construction; the oldest structures that have been removed from use are brick and concrete. There is an urgent need for updated guidance on the sustainable deconstruction of these different types of structures.

Design for deconstruction (DfD) has become a growing focus within in the C\&D waste community because DfD promotes efficiencies and recycling/reuse opportunities at the end of a building's useful life, and because DfD can help resolve various process issues experienced at the point of deconstruction. Some of these issues include but are not limited to:

- time required to take down buildings

- overall economics regarding deconstruction

- lead-based paint covered materials

- loss of materials at the point of disassembly

- storage of materials

- market survey analysis for material distribution.

DfD will help to reduce or resolve all of these issues by designing buildings to be deconstructed at the end of their useful life, so that building components (currently regarded as "waste") can be economically recovered and reused. At the time of construction, the new building design specifies the methods of disassembly; this simplifies and speeds disassembly for recycling or reuse. What makes DfD so beneficial is that the design specifies the materials to be used in the building, where they will be located, and how to most effectively remove them to take advantage of maximum value. Constructing buildings from components designed for quick and easy removal also makes it simpler to adapt or change the building to meet the evolving functions of the building over its useful life. Some of the principals involved with DfD include:

- simplification and standardization of connection details

- consideration of worker safety during construction and deconstruction phases

- reduction of building complexity 
- simplification and separation of building systems

- design to include reusable materials worth recovering

- design for flexibility and adaptability

- design for prefabrication and preassembly using modular components and assembly.

The great number of buildings being demolished and replaced on Army installations highlights the growing need to replace older buildings with more functional buildings that meet the continuing needs of Soldiers and other Army personnel. This unmet need provides a great opportunity to improve installations' ability to meet the Army NZW mandate and the SSPP Policy update by designing buildings with deconstruction in mind. Such designs will make it simpler and easier for contractors' to implement the deconstruction directive and to salvage the maximum amount of valuable material possible.

There is currently no set guidance for how deconstruction is to be planned or performed in the Army. While the Facilities Reduction Program (FRP) has some experience with deconstruction work through the Fort Leonard Installation, no deconstruction contract mechanism is yet in place to help contractors in that effort so that expectations are known and met. DfD can address this need, and many other issues that currently exist within the Army's management of C\&D waste and within the FRP program. 


\section{Environmental Life Cycle Assessment}

The Army Net Zero Waste Hierarchy (Figure 3, p 10) emphasizes the preference for reducing production of waste, then re-purposing what cannot be avoided, and finally, recycling as a third tier option. As discussed, opportunities exist to reduce food waste through operational changes. However, establishing similar processes for municipal solid waste and construction materials can be more challenging. Any DfD practices implemented now will show benefit decades from now when those building are dismantled. In the meantime, there is limited ability to reuse building materials from concrete structures due to the degradation of engineered properties during the demolition process. As has been seen with municipal solid waste, the feasibility of recycling depends largely on the greater economy i.e., whether the materials are in demand at a high enough price to justify the cost of recycling.

However, decisions on waste management do not currently take into account the environmental impacts of the alternatives. Environmental life cycle assessment (Eco-LCA) is a methodology for inventorying and evaluating the environmental burdens induced during a process at each of the stages of its life, including manufacture of needed equipment to transportation between stages in the process. The environmental burden is composed of the inputs (e.g., resources used) and outputs (e.g., waste emissions) that are attributable to the product or process during its life cycle. In the case of waste management, different alternatives for reuse, recycling, and disposal-including landfilling - may require significant transportation or energy inputs and land use to accomplish. Performing an Eco-LCA on these alternatives can help identify and quantitatively describe these additional impacts. In some cases, it may be justified to spend more to reuse materials on site to avoid the fossil fuel consumption and land degradation associated with transporting those materials to a landfill. Eco-LCA can also be used to calculate the volume of waste material at which environmental impacts fall below an acceptable threshold, thus helping to develop future waste minimization targets. These decisions will differ by installation based on the specific conditions and options available at each site. The Engineer Research and Development Center, Environmental Laboratory (ERDC-EL) is experienced in the Eco-LCA methodology and has performed this type of assessment for sediment placement alternatives in civil works applications. 


\section{Conclusions}

Even though the Army has made good progress toward meeting diversion goals in recent years, this work concludes that there is a need to better emphasize waste minimization and waste avoidance practices. Further research is needed on practices and technologies that address materials earlier in their life cycle to prevent them from becoming part of the waste stream. Further areas of research and development include:

- Army-specific Design for Deconstruction guidance.

- Food waste tracking software.

- Decision tools for prioritizing food waste reduction plans given the tracking data.

- Decision tools for managing municipal solid waste and C\&D waste depending on the size, location, age, and resources of a given installation.

- Publications and presentation of Army waste management issues and research to develop better contacts with the academic and industry communities, and to find partners for pilot studies.

- Identification, aggregation, and review of regulatory barriers that limit the effectiveness of waste reduction and diversion techniques.

- Significant improvements in waste management across all installations, which will require the support and impetus of a policy directive and/ or changes in operational guidelines that currently make selection of more sustainable options difficult. Nevertheless, there is opportunity for continued research and demonstration projects to provide the scientific foundation for these improvements and to provide a basis for calculating potential cost savings that can further support any changes. 


\section{References}

American Society for Testing and Materials (ASTM). 2008. Standard Test Method for Determination of the Composition of Unprocessed Municipal Solid Waste. ASTM D5231 - 92(2008). West Conshohocken, PA: ASTM.

Assistant Chief of Staff for Installation Management (ACSIM). 2010. Qualified Recycling Program Handbook. Washington, DC: U.S. Army ACSIM, http:/ / www.usar.amy.mil/ Portals/ 98/ Documents/Amp/200RP\%20Hdlbk_FNAL_Nov_\%202010.pdf

Chen, J ., J . Tinjum, and T. Edil. 2013. Leaching of alkaline substances and heavy metals from recycled concrete aggregate used as unbound base course. Transportation Research Record: J ournal of the Transportation Research Board 2349:81-90.

Construction \& Demolition Recycling Association (CDRA). 2016. Construction \& Demolition Recycling Association. We page. Milwaukee, WI: CDRA, http:// cdrecyding.org

Department of the Army (DA). 2014. Sustainability Report 2014. Washington, DC: DA, http:// unwasaiearmy.mil/ Public/ ES/ doc/ Amy\%20Sustainability/20Report\%202014.pdf

Disposal of Recyclable Materials, Title 10 U.S.C. 2577, 2010, https:/ / www.gpo.gov/fdsys/ search/ pagedetails.action?collectionCode=USCODE\&searchPath=T itle+1\&granuleld=U SCODE-2010-title10-subtitleA-partV-chap153sec2577\&packageld =USCODE-2010titel0\&oldPath=1tle+10\%2FSubtitle+A\%2FPart+1V\%2FChapter+153\%2FSec. +2577\&fromPage Details $=$ trueccollapse $=$ falseCycord $=0$

Evangelista, L., and J . de Brito. 2007. Mechanical behavior of concrete made with fine recycled concrete aggregates. Cement and Concrete Composites 29(5):397-401.

Hammack, Katherine. 2011. Memorandum, Subject: "Participation as a Pilot Army Net Zero Installation." Washington, DC: Assistant Secretary of the Army for Installations, Energy and Environment (ASA[IE\&E]).

_ 2013. Memorandum, Subject: Sustainable Design and Development Policy Update. Washington, DC: Assistant Secretary of the Army for Installations Management, Energy, and Environment (ASA-IE\&E), http:/ / www.asaiearmy.mil/ Public/ IE/ doc/ ASA(IEE)-SDD-policy-update-(16-Dec-2013).pdf

Headquarters, Department of the Army (HQDA). 2007. Environmental Protection and Enhancement. Army Regulation (AR) 200-1. Washington, DC: HQDA, http:// uww.dodnaturalresources.net/ AR200-1_2007.pdf

- 2007. Operating Procedures for the Army Food Program. AR 40-22, DA PAM 30-22. Washington, DC: HQDA, https:// dma.ny.gov/ foodsenice/ docs/ references/DA PAM_30-22.pdf

_ 2012a. Installations making progress toward 'Net Zero' by 2020. Web page. Accessed 18 August 2015, http:// wuwarmy.mil/artide/ 72241/Installations_making_progress_toward_Net_Zero by 2020/ 
. 2012b. Army vision for net zero: Net zero is a force multiplier. Army Energy Program. Web page. Accessed 07 February 2013, http:/ / army energy.hoda.pentagon.mil/programs/ netzero.asp

2012c. Army Food Program. AR 30-22. Washington, DC: HQDA, https:/ / dma.ny.gov/foodservice/ docs/references/ new_AR_30-22.pdf

- 2014. Tri-Service Food Code. TB MED 530/ NAVMED P-5010-1/ AFMAN 48147_IP. Washington, DC: HQDA, http:// www.med.nay.mil/ directives/ Pub/5010-1.pdf

Headquarters, Installation Management Command (HQIMCOM). 2014. Non-Hazardous Solid Waste Management Policy. Policy Letter \#6-14. Uijeongbu, South Korea: U.S. Army Garrison (USAG) Red Cloud and Area I, https:/ / www.amy.mil/e2/ c/ downloads/ 432291.pdf

Headquarters, U.S. Army Corps of Engineers (HQUSACE), Naval Facilities Engineering Command (NAVFAC), Headquarters, US Air Force (HQUSAF); Office of the Deputy Under Secretary of Defense for Installations and Environment (DUSD[I\&E]). 2002. Selection of Methods for the Reduction, Reuse, and Recycling of Demolition Waste. Unified Facilities Criteria (UFC) 1-900-01. Washington, DC: HQUSACE, NAVFAC, HQUSAF, and DUSD(I\&E). Canceled without Replacement.

J ones, C. 2012. Recycled Concrete Aggregate: A Sustainable Choice for Unbound Base. Aurora, IL: Construction Materials Recycling Association (CMRA; now known as CDRA).

McHugh, J ohn M. 2014. Memorandum, Subject: "Net Zero Installations Policy.” Washington, DC: Secretary of the Army.

Napier, T. R., J . O. Flores, and R. L. Schneider. 2015. Application of Updated Construction and Demolition Waste Reduction Policy to Army Projects. ERDC/ CERL SR-15-1. Champaign, IL: Engineer Research and Development Center, Construction Engineering Research Laboratory (ERDC-CERL), http:/ / achc.sdp.sirsi.net/ dient/ search/ asset/ 1049608

Newcomb, A. 2016. Facilities Reduction Program Demolitions Fort Benning WWII Buildings. Web page. Huntsville, AL: U.S. Army Engineering and Support Center (USAEHSC), http:// uwwhnc. usace.army.mil/ Media/ Nens-Stories/ Artide/ 705931/ facilitiesreduction-program-demolitions-fort-benning-wwii-buildings/

North American Industrial Classification System (NAICS). 2012. All Other Nonmetallic Mineral Product Manufacturing. NAICS Code 32799. Ottawa, Ontario, Canada: Statistics Canada.

Pollution Prevention Act of 1990 (PPA). 1990. Public Law 101- 508, 104 Stat. 1388- 321 et seq.

Recycled Materials Resource Center (RMRC). 2016. Recycled Materials Resource Center. Web page. Madison, WI: University of Wisconsin, Madison, College of Engineering. 
U.S. Department of Defense (DoD). 1996. Department of Defense Instruction Number 4715.4. Pollution Prevention. Washington, DC: DoD, http:// biotech.law.lsu.edu/ blaw/ dodd/ corres/ pdf2/ i47154p.pdf

2012. U.S. Department of Defense Strategic Sustainability Performance Plan: FY2012. Washington, DC: DoD, http:/ / wuw.denix osd.mil/ sustainability/ dod-sspp/ unassigned/ dod-sspp-fy-2012/

U.S. Energy Independence and Security Act of 2007 (EISA). 2007. Public Law (PL) 110140. 12 J anuary 2007.

White House, The. 2000. Greening the Government through Leadership in Environmental Management, Executive Order (EO) 13148. Washington. DC: The White House Office of the Press Secretary. (Revoked), https:/ / wnw.gpo.gov fdsys/ pkg/ FR-2000-04-26/ pdf/ 00-10550.pdf

- 2007. Strengthening Federal Environmental, Energy, and Transportation Management. EO 13423. Washington. DC: The White House Office of the Press Secretary. (Revoked).

_. 2009. Federal Leadership in Environmental, Energy, and Economic Performance. EO 13514. Washington. DC: The White House Office of the Press Secretary. (Revoked), https:/ / www.gpo.gov/ fdsys/ pkg/ FR-2007-01-26/ pdf/ 07-374.pdf

. 2015. Planning for Federal Sustainability in the Next Decade. EO 13693. Washington. DC: The White House Office of the Press Secretary, https:/ / wwwwhitehousegov the-press-office/ 2015/ 03/ 19/ executive-order-planning-federalsustainability-next-decade

Worrell E., and M. Reuter (eds.). 2014. Handbook of Recycling: State-of-the-Art for Practitioners, Analysts, and Scientists. Elsevier. 


\section{Acronyms and Abbreviations}

\begin{tabular}{|c|c|}
\hline $\begin{array}{l}\text { Term } \\
\text { ACSIM }\end{array}$ & $\begin{array}{l}\text { Definition } \\
\text { Assistant Chief of Staff for Installation Management }\end{array}$ \\
\hline ANSI & American National Standards Institute \\
\hline AR & Army Regulation \\
\hline ASA(IE\&E) & Assistant Secretary of the Army for Installations, Energy and Environment \\
\hline ASTM & American Society for Testing and Materials \\
\hline BASOPS & Base Operations \\
\hline$C \& D$ & Construction and Demolition \\
\hline CASI & Center for the Advancement of Sustainability Innovations \\
\hline CDRA & Construction \& Demolition Recycling Association \\
\hline CEERD & US Army Corps of Engineers, Engineer Research and Development Center \\
\hline CERL & Construction Engineering Research Laboratory \\
\hline CMRA & Construction Materials Recycling Association \\
\hline CMU & Concrete Masonry Unit \\
\hline CRREL & Cold Regions Research and Engineering Laboratory \\
\hline DA & Department of the Army \\
\hline DAPAM & Department of the Army Pamphlet \\
\hline DFAC & Dining Facility \\
\hline DfD & Design for Deconstruction \\
\hline DoD & U.S. Department of Defense \\
\hline DODI & Department of Defense Instruction \\
\hline DOT & Department of Transportation \\
\hline DPW & Directorate of Public Works \\
\hline ECO-LCA & Environmental Life Cycle Assessment \\
\hline EISA & U.S. Energy Independence and Security Act of 2007 \\
\hline EL & Environmental Laboratory \\
\hline EO & Executive Order \\
\hline ERDC & U.S. Army Engineer Research and Development Center \\
\hline ERDC-CERL & $\begin{array}{l}\text { Engineer Research and Development Center, Construction Engineering } \\
\text { Research Laboratory }\end{array}$ \\
\hline ERDC-CRREL & $\begin{array}{l}\text { Engineer Research and Development Center, Cold Regions Research and } \\
\text { Engineering Laboratory }\end{array}$ \\
\hline ERDC-EL & Engineer Research and Development Center, Environmental Laboratory \\
\hline FRP & Facilities Reduction Program \\
\hline FY & Fiscal Year \\
\hline GSF & Gross Square Foot \\
\hline HQDA & Headquarters, Department of the Army \\
\hline HQIMCOM & Headquarters, Installation Management Command \\
\hline HQUSACE & Headquarters, U.S. Army Corps of Engineers \\
\hline HQUSAF & Headquarters, US Air Force \\
\hline
\end{tabular}




$\begin{array}{ll}\text { Term } & \text { Definition } \\ \text { LRC } & \text { Logistics Readiness Command } \\ \text { LTC } & \text { Lieutenant Colonel } \\ \text { MWR } & \text { Morale, Welfare, and Recreation } \\ \text { NAICS } & \text { North American Industrial Classification System } \\ \text { NAVFAC } & \text { Naval Facilities Engineering Command } \\ \text { NSN } & \text { National Supply Number } \\ \text { NZW } & \text { Net-Zero Water } \\ \text { O\&M } & \text { Operations and Maintenance } \\ \text { OMB } & \text { Office of Management and Budget } \\ \text { PL } & \text { Public Law } \\ \text { PPA } & \text { Pollution Prevention Act } \\ \text { QRP } & \text { Qualified Recycling Program } \\ \text { RMRC } & \text { Recycled Materials Resource Center } \\ \text { SAR } & \text { Same As Report } \\ \text { SDD } & \text { Sustainable Design and Development } \\ \text { SF } & \text { Standard Form } \\ \text { SME } & \text { Subject Matter Expert } \\ \text { SMM } & \text { Sustainable Materials Management } \\ \text { SR } & \text { Special Report } \\ \text { SSPP } & \text { Strategic SustainabilityPerformance Plan } \\ \text { UFC } & \text { Unified Facilities Criteria } \\ \text { USACE } & \text { U.S. Army Corps of Engineers } \\ \text { USAEHSC } & \text { U.S. Army Engineering and Support Center } \\ \text { USAG } & \text { U.S. Army Garrison } \\ \text { USEPA } & \text { US Environmental Protection Agency } \\ \text { WMI } & \text { World War II } \\ & \end{array}$




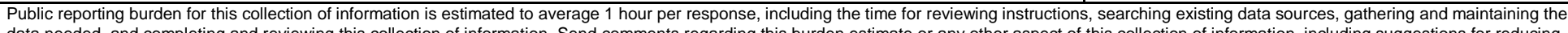

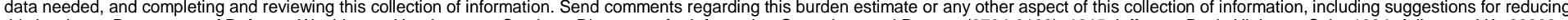

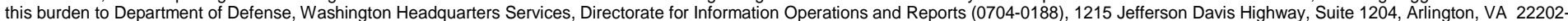

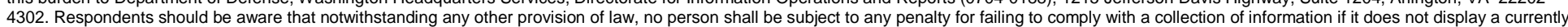
valid OMB control number. PLEASE DO NOT RETURN YOUR FORM TO THE ABOVE ADDRESS.

\begin{tabular}{l|l} 
valid OMB control number. PLEASE DO NOT RETURN YOUR FORM TO THE ABOVE ADDRESS. \\
\hline 1. REPORT DATE (DD-MM-YYYY) & 2. REPO
\end{tabular}
02/17/2017 Final

\section{TITLE AND SUBTITLE}

Material Life Cycle Analysis for the Reduction of Waste Generation at Military Installations

\section{AUTHOR(S)}

Giselle Rodriguez, Dominique Gilbert, M. Zillur Rahman, J orge Flores, Peter Stynoski,

Cate Fox-Lent, and Igor Linkov

3. DATES COVERED (From - To)

5a. CONTRACT NUMBER

5b. GRANT NUMBER

5c. PROGRAM ELEMENT

5d. PROJECT NUMBER

CASI

5e. TASK NUMBER

5f. WORK UNIT NUMBER

\section{PERFORMING ORGANIZATION NAME(S) AND ADDRESS(ES)}

Construction Engineering Research Laboratory (CERL)

US Army Engineer Research and Development Center (ERDC)

2902 Newmark Dr,

Champaign, IL 61824

8. PERFORMING ORGANIZATION REPORT NUMBER

ERDC SR-17-1

\section{SPONSORING I MONITORING AGENCY NAME(S) AND ADDRESS(ES)}

Center for the Advancement of Sustainability Innovations (CASI)

US Army Engineer Research and Development Center (ERDC)

2902 Newmark Dr

Champaign, IL 61824

10. SPONSOR/MONITOR'S ACRONYM(S)
CEERD-CZT

11. SPONSOR/MONITOR'S REPORT NUMBER(S)

\section{DISTRIBUTION I AVAILABILITY STATEMENT}

Approved for public release; distribution is unlimited.

\section{SUPPLEMENTARY NOTES}

\section{ABSTRACT}

In 2011, the U.S. Army implemented the Net Zero Initiative, which includes Net Zero Energy, Net Zero Water, and Net Zero Waste (NZW). A NZW installation is an installation that reduces, reuses, and recovers waste streams by converting them to resource value without using a landfill. To assist in that effort, this work reviewed the policies and initiatives aimed at reduction waste generation, discussed the challenges on the implementation of improvement efforts, and outlined existing research and operational needs to support more efficient operations and the achievement of Net Zero goals.

\section{SUBJECT TERMS}

Military bases, Integrated solid waste management, Waste Minimization, Sustainable engineering, Sustainability

\begin{tabular}{|c|c|c|c|c|c|}
\hline \multicolumn{3}{|c|}{ 16. SECURITY CLASSIFICATION OF: } & \multirow{2}{*}{$\begin{array}{l}\text { 17. LIMITATION } \\
\text { OF ABSTRACT } \\
\text { SAR }\end{array}$} & \multirow{2}{*}{$\begin{array}{l}\text { 18. NUMBER } \\
\text { OF PAGES } \\
42\end{array}$} & 19a. NAME OF RESPONSIBLE PERSON \\
\hline $\begin{array}{l}\text { a. REPORT } \\
\text { Unclassified }\end{array}$ & $\begin{array}{l}\text { b. ABSTRACT } \\
\text { Unclassified }\end{array}$ & $\begin{array}{l}\text { c. THIS PAGE } \\
\text { Unclassified }\end{array}$ & & & $\begin{array}{l}\text { 19b. TELEPHONE NUMBER } \\
\text { (include area code) }\end{array}$ \\
\hline
\end{tabular}

